\title{
Genesis of Nomadic Cattle Breeding in Mongolia and Southern Trans-Baikal Territory: Prerequisites and Reasons
}

\author{
Aleksandr D. Tsybiktarov* \\ Banzrov Buryat State University \\ Ulan-Ude, Russian Federation
}

Received 25.05.2020, received in revised form 28.08.2020, accepted 24.09.2020

\begin{abstract}
The article reveals the prerequisites and reasons for development of nomadic cattle breeding in the paleo-economy of the nomadic population of Mongolia and southern Trans-Baikal Territory. The article analyses the changes that occurred in the economic activities of the archaeological cultures of the region during the Bronze Age. The complex type of economy of the Selenga-Daurian culture of the EneolithicEarly Bronze Age is characterised, which combined the branches of the producing and appropriating economy. The sedentary lifestyle of representatives of the Selenga-Daurian culture is grounded. The nomadic nature of the economy and lifestyle of the population of the culture of tiled graves of the developed Late Bronze Age is shown. The change of cattle breeding in the local type to nomadic cattle breeding is associated with aridisation of the climate which began at the end of the 3rd millennium BC and ended in the middle of 2 nd millennium BC. The economic, biological and natural-climatic prerequisites for the transition to nomadism are highlighted including the accumulation of experience in the field of cattle breeding in the Early Metal Age, the adaptive abilities of farm animals for keeping in the open air, changes in the natural environment in the direction of climate aridisation and xerophytisation of vegetation steppes. The reason for the transition to nomadic cattle breeding was the establishment of severe continental climate with hot, dry summers and winters with little snow in the region in the middle of the 2 nd millennium $\mathrm{BC}$. The arid climate worsened the conditions for farming, hunting, fishing and gathering. The small thickness of the snow cover in winter made it possible to switch to year-round keeping of animals on pasture with periodic change of pastures as they were depleted. As a result, the economy of the steppe population was reorganised into nomadic cattle breeding and a mobile nomadic way of life of the population was formed.
\end{abstract}

Keywords: Bronze Age, paleo-economy, nomadic cattle breeding, paleogeography, paleoecology, interdisciplinary communications, aridisation, transformation, SelengaDaurian culture of tiled graves.

Research area: archeology.

(C) Siberian Federal University. All rights reserved

* Corresponding author E-mail address: a.d.tsibiktarov@gmail.com 
Citation: Tsybiktarov, A.D. (2020). Genesis of nomadic cattle breeding in Mongolia and southern TransBaikal Territory: prerequisites and reasons. J. Sib. Fed. Univ. Humanit. Soc. Sci., 14(1), 148-162. DOI: $10.17516 / 1997-1370-0577$.

\section{Introduction}

The paleo-economy of the population of Mongolia and southern Trans-Baikal region, representing the northern part of the territory of Central Asia, has been diversified since the Eneolithic and Early Bronze Ages. It includes both manufacturing and appropriating industries. However, from the end of the Bronze Age - the beginning of the Early Iron Age, it was based on cattle breeding, in some areas of the region it was nomadic, in others it was semi-nomadic. The specificity of the economy determined not only many features of the material and spiritual culture of the inhabitants of these regions of Central Asia, but also influenced their ethnocultural and political development. From the turn of the epochs to the time of the developed Middle Ages, the population of the steppes of Mongolia created large state formations in the form of nomadic empires, which included the steppes of southern Trans-Baikal region. The formation of these states was based on nomadic and semi-nomadic cattle breeding. In this regard, the issue of the genesis of the nomadic way of life in the paleo-economy of the steppe population of Central Asia is one of the most important problems in the history of the region.

Both domestic and international researchers turned to it. First of all, these are domestic and Mongolian scientists. In Russian science, researchers of the 1920s believed that the considered form of farming according to archaeology was recorded in the Central Asian population from the Scythian Epoch, from the 7 th to the 3 rd centuries $\mathrm{BC}$, i.e. even before the formation of nomadic empires. This was evidenced, in their opinion, by osteological materials from tiled burials allocated by G.I. Borovka and G.P. Sosnovskii into a separate archaeological culture in the mid-1920s and 1930s. Based on the analysis of artefacts from the Mongolian and Trans-Baikal graves, the researchers reasonably dated this culture to the Scythian Epoch (Borovka, 1927: 43-88;
Sosnovskii, 1941: 273-309). G.P. Sosnovskii spoke about the economic activities of culture bearers. Based on the fact that the overwhelming majority of bones from the graves belong to domestic animals (horses, small ruminants and cattle), as well as the possibility of their grazing in winter (small depth of snow), he concluded that nomadic cattle breeding appeared here with seasonal migrations in the Scythian Epoch (Sosnovskii, 1941: 273-309). This opinion was supported by S.V. Kiselev and A.P. Okladnikov, whose expeditions included more extensive excavations of these monuments in Mongolia and Trans-Baikal region in the late 1940s - 1950s (Kiselev, 1954: 46-51; Okladnikov, 1954: 9-48; Okladnikov, 1956: 21-107).

In the late 1950s - mid 1960s the entire scope of materials accumulated since the pre-revolutionary time on the culture of tiled graves was examined in detail by N.N. Dikov for the Trans-Baikal region and V.V. Volkov for Mongolia. They dated the culture to the Scythian Epoch, from the 7th to the 3rd centuries BC. Based on the analysis of statistical data on the ratio of bones of different species of domestic animals obtained from 98 burials of Southern Trans-Baikal region and 18 graves of Mongolia, taking into account the natural and climatic features of the steppes of these regions and ethnographic parallels in the economy of the Buryats and the Mongols, the scientists convincingly showed that cattle breeding among the population the culture of tiled graves was nomadic (Dikov, 1958: 108; Volkov, 1967: 148). In the mid-1970s and early 1980s a Mongolian researcher D. Navaan and Yu.S. Grishin came to the same conclusions about the nature of the economy of this culture based on the materials of excavations of more than 70 tiled graves in eastern Mongolia and several dozen burials in eastern Trans-Baikal region (Navaan, 1975: 200; Grishin, 1981: 204). This opinion was reflected in the early 1990 s in the generalising work on archaeology of the Scythian and Hunno-Sarmatian 
Epochs of the steppe zone in the territory of the former USSR in the area of the Trans-Baikal region written by N.L. Chlenova (Chlenova, 1992: 247-254). It should be noted that A.P. Okladnikov and Yu.S. Grishin suggested that it is likely that some of the tiled graves could be attributed to the developed Bronze Age (Okladnikov, 1959: 114-132; Okladnikov and Zaporozhskaya, 1970: 264; Grishin, 1981: 204). D. Navaan, I.V. Aseev and E.A. Novgorodov admitted the possibility of dating some of them even by the time of the Early Bronze Age (Navaan, 1975: 200; Aseev, 1985: 34-40; Novgorodova, 1989, 383). However, these ideas were not justified by extensive argumentation (see the above works).

Summing up the brief review of historiography on the formation of nomadic cattle breeding in the region of Mongolia and the southern Trans-Baikal region, the following main points can be outlined. The researchers' common opinion about the nomadic and semi-nomadic nature of cattle breeding among the population of the culture of tiled graves noted the existence of this economic structure in the steppe and forest-steppe regions of the region during the Scythian Epoch. The issues on the genesis of nomadic cattle breeding, the prerequisites and the reasons for its appearance, were practically not raised in the above mentioned works or they were covered in the most general terms. When reconstructing the nomadic economic structure of the bearers of the indicated culture, all the researchers proceeded from the mobile nature of the herd they identified, based on an analysis of the ratio of animal bones in burials, and the assumption that ancient cattle breeders lived in a severe continental climate with hot, dry summers and winters with little snow. The latter can be explained by the almost complete lack of information on the paleogeography of the territory of Mongolia and the southern Trans-Baikal region (Volkov, 1967: 148; Grishin, 1981: 204). Targeted research in this direction began to unfold only in the mid1970s. Given the emergence in recent decades of the 20th century and in the 2000s of paleogeographic materials, the author of the article also addressed the problem under consideration (Tsybiktarov, 2003: 49; Tsybiktarov, 2007:
194-198). However, the ideas expressed will be more fully reflected in this article.

Problem statement. Despite the constant attention of domestic and Mongolian archaeologists to the problem being raised since the 1920s and until now, the state of its various aspects is characterised by a different degree of elaboration. Researchers have no doubt that nomadic cattle breeding in the region of the southern Trans-Baikal region and Mongolia was the main economic activity of the population of the culture of tiled graves. However, the fact that nomadic cattle breeding was in the structure of the paleo-economy of the bearers of this culture does not resolve the issue of the genesis of this area of economic activity in its life support system. It is this problem that the article will focus on. The most important of them are the identification of the prerequisites and reasons for the transition of the ancient inhabitants of these regions of Central Asia to nomadic and semi-nomadic cattle breeding and the reflection of the transition in the materials of archaeological sites. The insufficient attention of researchers to these aspects of the issue was largely due to the fact that until the 1980s and 2000s the culture of the population of the Mongolian and Trans-Baikal steppes of the time of the Eneolithic-Early Bronze Age (Early Metal Age), which preceded the formation of the culture of tiled graves, was known only in the most general terms and actually remained unrecognised. This time period was designated as the Fofanovo stage of the Eneolithic-Early Bronze Age in the western Trans-Baikal region and dated mainly to the 2nd millennium BC (Ivashina, 1979: 158), and the Budalan stage of the Late Neolithic-Early Bronze Age of the middle $3 \mathrm{rd}$ - the middle 2nd millennium BC in the eastern Trans-Baikal region (Grishin, 1981: 204; Okladnikov, Kirillov, 1980: 176). In the regions of eastern and central Mongolia adjacent to the Trans-Baikal region, the main territory for the distribution of the tiled grave culture, the monuments of the Early Metal Age were studied even more poorly (Okladnikov, Larichev, 1969: 108-111; Derevyanko, Okladnikov, 1969: 141-156; Okladnikov, Derevyanko, 1970: 3-20, etc.). Considering the problem being raised, the influence of the new economic 
structure on different aspects of the life of the population in the steppes and forest-steppes of the southern Trans-Baikal region and Mongolia cannot be ignored.

Resolving the issue of the formation of nomadic cattle breeding in the steppes of Mongolia and the southern Trans-Baikal region suggests, in our opinion, the development of the following areas:

1) A comparative analysis of the archaeological cultures of the steppes of the southern Trans-Baikal region and Mongolia of the developed Bronze Age - Scythian Epoch and the previous time of the Eneolithic-Early Bronze Age (Early Metal Age) in order to identify similarities or differences in the structure of paleo-economy and the lifestyle of the population;

2) Assessment of the ecological environment of the population during these ages in order to establish their possible impact on changes in the economic activities of the steppe population, which, in turn, could affect the economic and cultural type and way of life;

3) Identification of the prerequisites and reasons that contributed to the transition of the inhabitants of the steppes of the southern Trans-Baikal region and Mongolia to nomadic cattle breeding;

4) Development of a possible model for the genesis of nomadic cattle breeding in the region based on the generalisation of the data obtained.

The steppe spaces of the north of Central Asia include the steppes of the southern Trans-Baikal region and Mongolia and cannot be separated from each other in cultural and historical terms. Firstly, archaeological monuments of the culture of tiled graves, widely distributed over the territory of these regions, prove this fact. Secondly, in the physical and geographical respect, the natural zones of the southern Trans-Baikal region and Mongolia are of the same type over the entire area of territorial contact. Thus, the middle-altitude mountainous country located between Khangai and Khentei in Mongolia in the north smoothly passes into the territory of the western Trans-Baikal region, where it is known as the Selenginsky high mountains (Murzaev, 1952:
472; Predbaikal'e ..., 1965: 492; Preobrazhenskii et al., 1959: 218). Likewise, the plains of eastern Mongolia are heading northward to the eastern Trans-Baikal region, where they were called the Uldz-Torey Plain and the Onon Depression (Murzaev, 1952: 472; Predbaikal'e ..., 1965: 492; Tipy mestnosti, 1961: 158). Thus, the landforms and climatic features of these regions on the territory of Mongolia and the Russian Federation created favourable conditions for economic, cultural and ethnic contacts between groups of the population living on their territory.

\section{Methods and approaches to the problem}

The article reveals the problem that requires an integrated approach with implementation of methods of natural sciences and STEM fields. The materials of archaeological excavations of the ancient inhabitants in the region provide us with numerous discoveries of bone remains of domestic animals. Statistical processing of these sources allows us to talk about the ratio of different species of animals that were bred by the steppe inhabitants, and the composition of the herd. Therefore, we can conclude on the type of cattle breeding. The results of paleogeographic and paleosoil studies at the territory of Mongolia and the Trans-Baikal region characterise the natural and geographical conditions in which the inhabitants of these regions lived and adapted to in the Bronze and Early Iron Ages. This vector of studying the topic is of fundamental importance due to the fact that the ecological environment directly influenced the formation of the economic activities of ancient people and the modifications, and sometimes radical transformations that occurred therein. Nomadic cattle breeding reflects one of the stages in the history of paleo-economy of the ancient population of the Great Steppe Belt of Eurasia. It included the Mongol-Transbaikal steppes. This circumstance determines the application of the comparative historical method by comparing the characteristics of the economic activities of the population of Mongolia and the Trans-Baikal region of different periods of the Bronze Age in order to identify changes in the development of their 
paleo-economy. Taking into account the lack of narrowly dated artefacts in tiled graves, radiocarbon dating of these monuments is of great importance for determining the range of their existence. The widespread use of this dating method provides important information about the time when the severe continental climate was established in the region, which was an important prerequisite for the transition to nomadic forms of cattle breeding and indirectly indicated possible dating of this event in the steppes of Mongolia and the Trans-Baikal region. Thus, only the application of an integrated approach using archaeological, general historical, natural science and statistical methods can contribute to reasonable investigation of the problem raised in the article.

\section{Discussion}

The culture of tiled graves was spread over the vast territories of Central Asia, over the territory of the Russian Federation, Mongolia and the People's Republic of China. The study of this culture took place within the borders of the three indicated states. This is proved by generalisations of the culture under study provided by N.N. Dikov on the Trans-Baikal region and by V.V. Volkov on Mongolia in the 1950s-60s, by D. Navaan on Mongolia and by Yu.S. Grishin on the Trans-Baikal region in the 1970s-80s. For the entire area of the culture of tiled graves, basing on the published and archival materials, the author of the article collected information about the excavations of 542 burials at 201 cemeteries at the territory of the USSR-Russia and Mongolia. These include 247 graves in the Republic of Buryatia (92 burial grounds), 124 graves in the Trans-Baikal Territory (55 burial grounds) and 171 graves in Mongolia (54 burial grounds).

Animal bones were found in 187 tiled graves out of 542 , which is $34.5 \%$ of the total number of funerary objects ${ }^{1}$. Moreover, only

\footnotetext{
Note: in fact, the percentage of occurrence of animal bones in tiled graves should be much higher. Until the 1980s during the excavation of tiled graves both on the territory of the USSR and in Mongolia, it was not the entire structure that was usually studied, but only the space inside the rectangular fence. This omission in the excavation technique affected the representativeness of the discovered finds. In all cases of exca-
}

in nine of them (4.8\%) bones of wild animals were found. These data convincingly indicate that cattle breeding was the main source of meat among the population of the tiled grave culture, and hunting was of secondary importance. With regard to the ratio of bones of domestic animals, the following circumstances are noteworthy. Horse bones were found three times more often than (indicator 3.25) cattle bones, and bones of small cattle compared to the cattle - two times more often (indicator 2.16). As a result, new data from a more quantitatively representative sample (187 tiled graves with bones of domestic animals) compared with the information of N.N. Dikov (98 graves) and V.V. Volkov (18 graves), confirmed the conclusions about the predominance of horse and small cattle bones in tile graves in comparison with cattle bones. This indicates the mobile nature of the herd of domestic animals in the population of the culture and the nomadic type of cattle breeding.

In recent decades, significant changes have taken place regarding the dating of the culture of tiled graves. In the late 1980s and in the 1990s it was proved that it is firmly dated not only by Scythian Epoch, i.e. 8th - 3rd centuries $\mathrm{BC}$, but also by the Late Bronze Age, synchronous to the Karasuk Epoch according to the chronostratigraphy of the Bronze Age of Southern Siberia, i.e. 13th - 8th centuries BC. (Tsybiktarov, 1989: 24; 1998: 288; Erdenebaatar, 1997: 23). In the early 2000s the time of the beginning of its existence was deepened to the middle of the second millennium $\mathrm{BC}$, i.e. the period of the Developed Bronze Age (Tsybiktarov, 2003: 49). However, a revision of the prevailing ideas about dating the culture of tiled graves does not solve the problem of the origin of nomadic cattle breeding in the steppes of Mongolia and the southern Trans-Baikal region. The change in the dating of the culture, first to the beginning of the Late Bronze Age, and then - the period of the Developed Bronze Age only shifted the time of its presence in the

vation of tiled graves, when their entire structure was studied, including crepidoma outside the fence, artefacts, including animal bones, almost always, with rare exceptions, were found outside the fences on the crepidoma stones and between them (see Tsybiktarov, 1988: 40-60). 
structure of economic activities of the steppe inhabitants in the region to the middle of the 2nd millennium BC.

\section{Comparative analysis of the steppe archaeological cultures of the southern Trans-Baikal region and Mongolia of the Eneolythic - Early Bronze Age and the Developed BronzeAge - Scythian Epoch}

It has already been noted above that until the end of the 1970s and the beginning of the 1980s the culture of the population of the eastern part of the Mongol-Transbaikal steppes of the time of the Eneolithic-Early Bronze Age (Early Metal Age) was actually not allocated and was designated as chronological stages. Turning to the materials accumulated by the beginning of the 2000s on the Early Metal Age of the steppe and forest-steppe areas of the Trans-Baikal region and eastern Mongolia from the middle Selenga basin in the west to Onon, the Shilka and Argun interfluve in the east allowed to distinguish the archaeological culture of this time, called the Selenga-Daurian culture (Tsybiktarov, 2003: 49; Tsybiktarov, 2006: 236). The time of its existence was determined by the end of $3 \mathrm{rd}$ - the middle of the $2 \mathrm{nd}$ millennium BC. The well-preserved cultural layers of the settlements Dvortsy, Zhigurzhinka I, Kirochi, Kharga I, Kulkison and others were up to $25-50 \mathrm{~cm}$ thick. They contained a variety of stone and bone accessories, ceramics, and a large number of animal bones. The evidence of not only the acquaintance of culture bearers with metal, but also the beginning of its smelting are the findings of not only individual products, but also copper-bronze waste and metal droplets in the cultural layers of monuments and burials.

Bones of wild and domestic animals were found in the settlements. Wild animals were represented by the animals of the steppe, forest-steppe and taiga landscapes: roe deer, elk, red deer, wild boar, musk deer, dzeren, onager, tarbagan marmot, badger, fox, hare, and goose, duck, heron and the great bustard from birds. The bones of domestic animals belonged to horse, bull, cow, sheep and dog. Deep pits, about $1.5 \mathrm{~m}$, were used for salting and storing fish. Stone tools included those related to hunting, fishing, gathering, farming, and processing products of these types of economic activities. The predominance of the bones of wild animals and fish among osteological materials indicates that in the Early Metal Age appropriating types of farms still played a significant role in the economy of the population of the Selenga-Daurian culture. Agricultural tools and bones of domestic animals testify to occupations in agriculture and cattle breeding. Thus, the paleo-economy of the inhabitants of the settlements in the southern Trans-Baikal region and eastern Mongolia of the end of the 3rd - the first half of the 2nd millennium BC is characterised as diversified, combining appropriating and producing industries. The thickness of the cultural layer in the settlements of several tens of centimetres indicates a long residence of the inhabitants in one place, i.e. a settled way of life. However, in places of seasonal fishing and the location of hunting camps, extraction of stone raw materials, temporary camps could have also existed (Tsybiktarov, 2006: 236). It should be noted that the data indicating that the village residents of the Selenga-Daurian culture were occupied in production activities, which appeared in the Trans-Baikal region and eastern Mongolia during the Developed Neolithic Age (Okladnikov, Derevyanko, 1970: 3-20; Okladnikov and Kirillov, 1980: 176; Grishin, 1981: 204; Derevyanko, 1986: 234-250; Dorzh, 1990: 37; Tseveendorzh et al., 2008: 239). A sufficiently large thickness of the cultural layer, which implies a settled way of life, indirectly indicates the presence of crops near the settlements and the house-keeping shepherd character of cattle breeding of the Mongol-Transbaikal population of the Early Metal Age. Probably, the epoch in question was the time of continued accumulation of experience in managing of the production and restructuring of the economy that began, due to an increase in the volume of skills in farming and cattle breeding.

In the funeral rite of the population of the Selenga-Daurian culture, during the Early Metal Age, a departure from Neolithic traditions was observed, accompanied by the emergence of innovations under the influence of the producing economy in the construction of grave- 
stones, the position of the dead, accompanying inventory. Meat of domestic animals was used for ritual purposes (Tsybiktarov, 2006: 236). Changes occurred in spiritual culture that were reflected in the appearance of cave paintings (ibid.)

The paleo-economy of the population of the culture of tiled graves of the Developed, Late Bronze and Scythian Ages (mid 2nd millennium - 3rd century BC) also had a diversified character. However, its main industry was nomadic and semi-nomadic cattle breeding. Other industries such as agriculture, hunting, fishing, gathering, were of secondary importance. Bronze metallurgy reached quite a high level. Various homemade productions were well developed including ceramics, bone-carving, weaving, stone processing, and the products of various branches of the producing and appropriating economy. The funeral rite was mainly influenced by cattle breeding and its nomadic nature. This feature found expression in the cave art of the bearers of the culture of tiled graves - the Selenga type petroglyphs which displayed the ideas of cattle fertility, first of all (Sosnovskii, 1941: 273-309; Kiselev, 19541: 46-51; Okladnikov, 1954: 9-48; 1956: 21-107; Okladnikov, Zaporozhskaya, 1969: 220; 1970: 264; Dikov, 1958: 108; Volkov, 1967: 148; Navaan, 1975: 200; Grishin, 1981: 204; Tsybiktarov, 1998: 288; Tsybiktarov, 2018: 173-189).

The mobile form of cattle breeding led to the nomadic and semi-nomadic lifestyle of the population of the culture of tiled graves. This is evidenced by the nature of settlement cultural monuments. The territory of Mongolia and the Trans-Baikal region contains hundreds of temporary, so-called dune sites, where fragments of ceramics, tools, jewelry, weapons, accessories of horse harness made from bronze and other materials were found, similar to objects from tiled graves. At the same time, settlements with powerful cultural layers were not identified. One of the evidences of a nomadic way of life is the similarity in the planigraphy of the location of fences on the burial grounds and the location of the Mongolian yurts at individual sites during migrations. (Tsybiktarov, 2018: 173-189).
A comparison of the economy and lifestyle of the bearers of the Selenga-Daurian culture and the culture of tiled graves shows both a certain similarity and cardinal differences. These cultures are similar due to the complex structure of their economies, they were diversified. However, the ratio of sectors of the economy was different. In general, in the Early Metal Age, hunting and fishing remained of great importance, as in the Neolithic. Agriculture and cattle breeding in comparison with them probably played not such a significant role, but their importance seemed to increase with time, which was reflected in the funeral rite. In subsequent periods of the Bronze Age and in the Scythian Epoch, cattle breeding came to the fore. It became the basis of the economy, while the importance of hunting, fishing, and farming decreased. The nature of cattle breeding also changed. During the Eneolithic and Early Bronze Age period, it was pastoral. During the culture of tiled graves, cattle breeding became nomadic. The way of life of the steppe population of the region began to differ. The carriers of the Selenga-Daurian culture led a sedentary lifestyle. The culture of tiled graves was characterised by nomadic way life.

The results of the comparative analysis indicate that during the transition from the Early Bronze Age to the Developed Bronze Age, there was a change in the type of economy and lifestyle of the steppe population of Mongolia and the southern Trans-Baikal region, i.e. in general, the economic and cultural type. It can be assumed that by the end of the Early Metal Age, the manufacturing industry came to the forefront in the economic activities of the steppe population, and with the advent of the Developed Bronze Age, cattle breeding began to play a decisive role in its economy and acquired a semi-nomadic or nomadic character.

\section{Paleogeography of Mongolia and the southern Trans-Baikal region of the Neolithic and Bronze Age}

Studies conducted in Mongolia in the 1970s and 2000s made it possible to represent the natural environment of the region at different periods of geological history, including the Holocene. The Mid-Holocene period 
$(8,000-4,000$ years BP) in Mongolia is characterised by chilly and more humid climate. In the mountains in the north, centre and west of Mongolia, dark coniferous forests begin to spread rapidly; mountain landscapes predominate. Forest-steppe landscapes with island coniferous and mixed forests developed on the mountain slopes of the central part of the country. The steppes replaced the deserts in the northwest and generally dominated throughout the country. In the northeast of Mongolia in the valley of the Uldza river the oak penetrates from the east. Even the treeless, now arid plains of eastern Mongolia at that time could be heavily forested. The steppes of Mongolia were mostly meadows. In Mongolia, the border between the Middle and Upper Holocene passes at about 4,000 years BP. At the turn of these periods, environmental conditions became less favourable than in the Mid-Holocene, climate aridisation began. The dry and cold climate at the turn of the Atlantic and Subboreal periods (end of 3rd - beginning of 2nd millennium BC) was replaced by a phase of dry warm climate in the second quarter of the 2nd millennium BC, which lasted for about 300 years. During this period, approximately 3,880-3,600 years BP, soils on the East Hangai and on the plains of the Eastern Mongolia were buried by aeolian sediments. Then from 3,500 to 3,300 years ago there is a short period of increased hydration, which then decreases. In the range of 4,000-3,000 years BP the levels of the lakes of the northern, central and eastern parts of Mongolia dropped significantly, the levels were below the modern ones. In general, the Subboreal period is characterised by an increase in continental and climate aridisation. During its course, there was an active replacement of dark coniferous and light coniferous forests with steppe vegetation. Taiga forests in Hangai were replaced by steppe after 4,250-4,000 years BP. In the now treeless Gobi Altai, dark coniferous forests lasted up to 3,800-3,500 BP. (Vipper et al., 1976: 35-59; Vipper et al., 1978: 19-24; Vipper et al., 1981: 74-82; Vipper et al., 1989: 160167; Dinesman, Kiseleva, Knyazev, 1989: 215; Dorofeyuk, 2008: 49). The data on paleogeography indicate that during the first half of the 2nd millennium BC in Mongolia, the climate and natural environment developed along the lines of increasing aridisation and continental climate, accompanied by xerophytisation of vegetation, displacement of forest vegetation by steppe. Perhaps by the middle of the 2 nd millennium $\mathrm{BC}$ severely continental climate was established.

According to the paleogeography of the southern Trans-Baikal region of the Middle and Late Holocene periods, there is no such detailed information as for Mongolia. However, the available data show that the general line of climate development here developed in a close direction (Okladnikov and Kirillov, 1980: 176; Lbova, Grechishchev, 1995: 7-17; Dergacheva et al., 1999: 77-81; Granina, Granin, Tsybiktarov, 1999: 427-428). Thus, the development of the climate and flora in Mongolia and the southern Trans-Baikal region during the Mid-Holocene and Subboreal periods, which coincided with the Neolithic and Bronze Ages, after the climatic optimum went towards aridisation of the climate and xerophytisation of steppe ecosystems. Information provided by paleogeographers on the peculiarities of the natural and climatic situation during these periods must be taken into account when analysing materials on the history of the population of Central Asia of the Bronze and Early Iron Age. Climate and environmental changes could have a significant impact on various aspects of the economic life of the population, and through them on various processes taking place in society, including the way of life of ancient people.

\section{Prerequisites and reasons \\ for the transition to nomadic cattle breeding}

The emergence of the producing economy in the steppe and forest-steppe regions of the southern Trans-Baikal and Eastern Mongolia occurred during the developed Neolithic period among the steppe population, which was called Onon in the USSR-Russia, and Tamsag-Bulak in Mongolia. Both agriculture and cattle breeding were represented there (Okladnikov, Derevyanko, 1970: 3-20; Okladnikov, Kirillov, 1980: 176; Grishin, 1981: 204; Derevyanko, 1986: 234-250; Dorzh, 1990: 37; Tseeveendorzh et al., 2008: 239). In the Late Neolithic, these sectors, while maintaining the predominant 
importance of hunting in economic activities, developed further. Agricultural tools began to appear in monuments of this period much more often, the number of bones of domestic animals - horses and cows - increased sharply (Okladnikov and Kirillov, 1980: 176). In the Early Metal Age, the population of the Selenga-Daurian culture experienced a further development of the manufacturing sectors as part of the integrated economy. It is very important that at this time, cattle breeding began to be reflected in the funeral rite, it started to include the ritual of using meat from domestic animals. This indicates the growing importance of this industry in the economy of the steppe population (Tsybiktarov, 2006: 236). The dynamics of the development of the producing economy during the Neolithic - Early Metal Age demonstrates the growth of its importance in the economy of the steppe population, especially with regard to cattle breeding. The materials of rock art confirm this as the subject, plots and compositions of the Selenga petroglyphs appear in it (Mazin, 1994: 241), which were further developed by nomadic cattle breeders of the subsequent periods of the Bronze and Early Iron Ages.

Success in the development of cattle breeding contributed to the accumulation of experience in this area. The population of the region studied grazing of different types of cattle in different seasons of the year, recognised the ability of animals to graze in winter and obtain fodder at the beginning of the winter cycle, which reduced the scope of fodder stocks for this period of the year, veterinary medicine started to develop, etc. Taking into account the changes in the climatic and landscape conditions in the direction of climate aridisation and xerophytisation of vegetation described above, which began from the turn of the $3 \mathrm{rd}-2$ nd millennium $\mathrm{BC}$, it is hardly doubtful that the totality of this diverse knowledge constantly increased and changed qualitatively. The accumulation of practical experience in cattle breeding took place and it should be assumed, in the direction of increasing productivity and identifying the adaptive capabilities of different types of domestic animals, horses, small cattle and cattle to changing climatic condi- tions. These circumstances created one of the prerequisites for the transition to nomadic cattle breeding - the identification of the ability of livestock species to be kept on pasture during winter periods with little snow in the climatic cycle of the southern Trans-Baikal region and eastern Mongolia.

Another prerequisite for the transition to nomadic cattle breeding was the restructuring of the paleo-economy of the population of the Asian steppes in the Bronze Age towards the development of the producing economy with cattle breeding as its main industry. In accordance with the laws governing the development of the economy of the steppes of Central Asia, Kazakhstan and South Siberia in the Bronze Age, which climatically coincided with the dry and warm Subboreal period of the Holocene, the development of agriculture and cattle breeding in Mongolia and the southern Trans-Baikal region should have also developed in the direction of increasing the importance of cattle breeding, when the steppes had almost unlimited reserves of fodder resources for livestock, and the lack of moisture, compared with the period of the climatic optimum of the Neolithic, and hard steppe soils prevented the increase of agriculture proportion in the structure of the producing industry. Considering this aspect, one cannot ignore such a factor as much higher nutritional properties, calorie content of meat food in comparison with products of plant origin, which ancient people had known since the Paleolithic period. This additionally stimulated the interest and attention of the steppe inhabitants in cattle breeding as the final result of hunting, which can be both successful and unsuccessful, was unpredictable.

Another prerequisite for putting the livestock to grass was high adaptive abilities of domestic animals of the ancient inhabitants of the Mongol-Transbaikal region to winter conditions. This is influenced by the following circumstances. Different types of cattle of the Mongols and Buryats, their origin associated with domestic animals that were bred by their distant ancestors up to the Middle Ages and the early Iron Age, were well adapted to live rough in winter. A good example of this is the fact that the lambing of the Buryat native sheep did 
not take place in specially prepared places, as it is done now, but directly under the open sky. Lambs already after 5-9 days began to graze in the common herd (Taishin, Lkhasaranov, 1997: 24). It should be assumed that the domestic animals of the people in the Early Metal Age were probably even less fastidious compared with the cattle of nomads that lived later.

The natural and climatic prerequisite for the transition to nomadic cattle breeding was climate change towards aridisation and the natural environment in the direction of expanding the steppe landscapes, xerophytising their vegetation, as well as reducing the area of forests, shallowing of water bodies. Such changes in nature not only worsened the opportunities for farming, but negatively affected the branches of the appropriating economy: hunting, fishing, and gathering. For wild animals, both in the steppe and forest zones, the food supply was reduced, as the plant productivity decreased due to lower climate humidity. This could not but affect the number of wild animals and decreased the scope of hunting. A decrease in the amount of precipitation affected the level of water in rivers and lakes, and therefore the fish resources of water bodies. At the same time, the expansion of steppe and forest-steppe landscapes increased the area of pastures for domestic animals, stimulating the development of cattle breeding among the steppe population. As the climate was getting drier, the amount of precipitation in winter decreased, which reduced the thickness of the snow cover and facilitated the access of livestock to pasture at this time of the year. This made it possible to increase the number of grazing days with the onset of winter, and in the future, with the establishment of a severely continental climate, to switch to keeping animals on pasture during the whole winter period.

Thus, the combination of a number of economic, biological, and natural-geographical factors (success in the development of the producing economy, accumulation of experience in cattle breeding in the Early Metal Age, adaptive abilities of farm animals for staying outdoors, changes in the natural environment) created prerequisites for the transition of the steppe population of Mongolia and southern
Trans-Baikal region from the home pastoral cattle breeding to its nomadic form, associated with year-round grazing with periodic change of pastures as they were depleted and by mobile way of life of the population.

The change in the economic structure and lifestyle of the steppe population of Mongolia and southern Trans-Baikal region - the transition from a complex type of economy with a combination of producing and appropriating branches associated with a settled way of life to nomadic and semi-nomadic cattle breeding with seasonal movements across pastures, was directly caused by the establishment in the region of a severely continental climate with hot, dry summers and winters with little snow. The natural features of the new climate created insurmountable conditions for the inhabitants of the Mongol-Transbaikal steppes to maintain the former balanced complex type of economy and lifestyle of sedentary cattle breeders and farmers, in the economic activities of which there was place for hunting, fishing, and gathering.

The life activity of people in all periods of the history of mankind, and especially at the early stages of its existence in antiquity, was largely associated with adaptation to environmental conditions. Forms of economic activities, tools, housing, clothing, people's knowledge of the world and other aspects of people's lives were largely associated with the development of the environment in order to meet their needs. As a result, the natural environment had a direct impact on the formation of the economy, the material and spiritual culture of human communities. Based on the above, it can be assumed that the process of climate aridisation that began in Mongolia and the southern Trans-Baikal region from the turn of the 3rd - 2nd millennium BC and completed by the middle of the $2 \mathrm{nd}$ millennium $\mathrm{BC}$ with the establishment of a more arid, in comparison with the initial period of the Early Metal Age, severely continental climate, was supposed to affect economic activities, material and spiritual culture of the region's population.

At the same time, the change in the climatic situation and the environment as a whole took place gradually, embracing by human standards the lives of people of more than one 
generation. Therefore, changes in the economic activity of the steppe population with the reduction of the role of agriculture and the appropriating branches of the economy and the growth of the importance of cattle breeding, with the subsequent formation of its nomadic type, occurred quite smoothly, parallel to the evolution of the climatic and landscape-soil situation in the region. By the middle of 2nd millennium $\mathrm{BC}$, when, according to paleogeography, a severely continental climate was established in the region, they finished with the reorganisation of the economic basis of the steppe population. Integrated diversified economy was replaced by nomadic and semi-nomadic cattle breeding. The change in the economic basis of life was accompanied by significant changes in the sphere of material and spiritual culture. Ultimately, in the middle of the 2nd millennium $\mathrm{BC}$ in eastern, partly central Mongolia and southern Trans-Baikal region, the Selenga-Daurian culture of the Early Metal Age was replaced by the culture of tiled graves. The first completed its development, and the second was formed on its basis and reflected the further existence of its population in the new historical period of Developed Bronze. Cattle-breeding farms of nomadic and semi-nomadic type already existed depending on natural conditions in different areas.

\section{References}

Aseev, I.V. (1985). K voprosu o datirovke mogil tipa chetyrekhugol'nykh ogradok [On the dating of graves such as quadrangular fences]. In Drevnie kul'tury Mongolii [Ancient cultures of Mongolia], Novosibirsk, Nauka, 34-40.

Borovka, G.I. (1927). Arheologicheskoe obsledovanie srednego techeniya r. Toly [Archaeological survey of the middle course of the river. Toli]. In Severnaya Mongoliya [Northern Mongolia], Leningrad, Akademiya nauk SSSR, II, 43-88.

Chlenova N.L. (1992). Kul'tura plitochnykh mogil [Tiled Grave Culture]. In Stepnaia polosa Aziatskoi chasti SSSR v skifo-sarmatskoe vremia. Arheologiia SSSR [Steppe zone of the Asian part of the USSR in Scythian-Sarmatian time. Archeology of the USSR], Moscow, Nauka, 247-254.

Derevyanko, A.P., Okladnikov, A.P. (1969). Drevnie kul'tury vostochnykh raionov MNR [Ancient cultures of the eastern regions of the MPR]. In Sovetskaia arheologiia [Soviet archeology], 4, 141-156.

Derevyanko, A.P. (1986). Drevnie kul'tury Mongolii [Ancient cultures of Mongolia]. In Arheologiia Zarubezhnoi Azii [Archeology of Foreign Asia], Moskva, Vysshaia shkola, 234-250.

Dergacheva, M.I., Fedeneva, I.K., Vashukevich, N.V., Granina, N.I. (1999). Prirodnye usloviia v epokhu pozdnei bronzy po pedologicheskim dannym [Natural conditions in the Late Bronze Age according to pedological data]. In Paleoekologiia cheloveka Baikal'skoi Azii [Human paleoecology of Baikal Asia], Ulan-Ude, Buriatskii nauchnyitscentr Sibirskogo otdeleniia RAN, 77-81.

Dikov, N.N. (1958). Bronzovyi vek Zabaikal'ia [Bronze Age of Transbaikalia]. Ulan-Ude, Buriatskoe knizhnoe izdatel'stvo, $108 \mathrm{p}$.

Dinesman, L.G., Kiseleva, N.K., Knyazev, A.V. (1989). Istoriia stepnykh ekosistem Mongol'skoi Narodnoi Respubliki. Biologicheskie resursy i prirodnye usloviia Mongol'skoi Narodnoi Respubliki [History of the steppe ecosystems of the Mongolian People's Republic. Biological resources and environmental conditions of the Mongolian People's Republic], 32. Moscow, Nauka, 215 p.

Dorzh, D. (1990). Kamennyi vek Mongolii. Avtoreferat dissertatsii na soiskanie uchenoi stepeni doktora istoricheskikh nauk [Stone Age of Mongolia. Abstract of dissertation for the degree of Doctor of Historical Sciences], Novosibirsk, $37 \mathrm{p}$.

Dorofeyuk, N.I. (2008). Rekonstruktsiia prirodnykh uslovii Vnutrennei Azii v pozdnelednikov'e $i$ golotsene (po materialam diatomovogo i palinologicheskogo analizov ozernykh osadkov Mongolii). Avtoreferat dissertatsii na soiskanie uchenoi stepeni doktora biologicheskikh nauk [Reconstruction of the natural conditions of Inner Asia in the Late Glacial and Holocene (based on diatom and palynological analyzes of lake sediments of Mongolia). Abstract of dissertation for the degree of Doctor of Biological Sciences], Moscow, 49 p. 
Erdenebaatar, D. (1997). Pamiatniki bronzovogo i rannego zheleznogo vekov basseina $r$. Selengi. Avtoreferat dissertatsii na soiskanie uchenoi stepeni kandidata istoricheskikh nauk [Monuments of the Bronze and Early Iron Ages of the river basin Selenga. Abstract of dissertation for the degree of candidate of historical sciences], Ulaanbaatar, $23 \mathrm{p}$.

Granina, N.I., Granin, A.V., Tsybiktarov, A.D. (1999) Spektral'naia otrazhatel'naia sposobnost' pochv, pogrebennykh pod kladkoi plitochnykh mogil $\mathrm{v}$ Zabaikal'e [Spectral reflectivity of soils buried under masonry of tiled graves in Transbaikalia]. In Geokhimiia landshaftov, paleoekologiia cheloveka $i$ etnogenez. Tezisy mezhdunarodnogo simpoziuma [Geochemistry of landscapes, human paleoecology and ethnogenesis. Theses of the international symposium], Ulan-Ude, Buryatskii nauchnyi tsentr Sibirskogo otdeleniia RAN, 427-428.

Grishin, Yu.S. (1981). Pamiatniki neolita, bronzovogo i rannego zheleznogo vekov lesostepnogo Zabaikal'ia [Monuments of the Neolithic, Bronze and Early Iron Ages of the forest-steppe Transbaikalia]. Moscow, Nauka, $204 \mathrm{p}$.

Ivashina, L.G. (1979). Neolit i eneolit lesostepnoi zony Buriatii [Neolithic and Eneolithic forest-steppe zone of Buryatia]. Novosibirsk, Nauka, $158 \mathrm{p}$.

Kiselev, S.V. (1954). Epokha proizvodstva orudii iz bronzy [The era of the production of tools from bronze]. In Istoriia Mongol'skoi narodnoi respubliki [History of the Mongolian People's Republic]. Moscow, Akademiia nauk SSSR, 46-51.

Lbova, L.V., Grechishchev, E.R. (1995). K probleme poselenii epokhi metalla stepnoi zony Zapadnogo Zabaikal'ia [On the problem of settlements of the metal age of the steppe zone of Western Transbaikalia]. In Kul'tury i pamiatniki bronzovogo i rannego zheleznogo vekov Zabaikal'ia i Mongolii [Cultures and monuments of the Bronze and Early Iron Ages of Transbaikalia and Mongolia], Ulan-Ude, Buriatskii nauchnyi tsentr Sibirskogo otdeleniia RAN, 7-17.

Mazin, A.I. (1994). Drevnie sviatilishcha Priamur'ia [Ancient Holy Places of the Amur Region]. Novosibirsk, Nauka, 1994, $241 \mathrm{p}$.

Murzaev, E.M. (1952). Mongol'skaia Narodnaia respublika. Fiziko-geograficheskii ocherk [Mongolian People's Republic. Physiographic sketch]. Moscow, Geograficheskoe gosudarstvennoe izdatel'stvo, 472 p.

Navaan, D. (1975). Bronze Age of Eastern Mongolia [Дорнод Монголийн хурлийн ye]. Ulan-Bator, Akademiia nauk Mongolii), $200 \mathrm{p}$.

Novgorodova, E.A. (1989). Drevnyaya Mongoliia [Ancient Mongolia]. Moscow, Nauka, 383 p.

Okladnikov, A.P. (1954). Epokha pervobytnoobshchinnogo stroia [The era of the primitive communal system]. In Istoriia Buriat-Mongol'skoi ASSR [The History of the Buryat-Mongol Autonomous Soviet Socialist Republic]. Ulan-Ude, Buriatskoe knizhnoe izdatel'stvo, 1, 9-48.

Okladnikov, A.P. (1956). Drevnee naselenie Sibiri i ego kul'tura [The ancient population of Siberia and its culture]. In Narody Sibiri [Peoples of Siberia], Moscow-Leningrad, Akademiia nauk SSSR, 21-107.

Okladnikov, A.P. (1959). Tripody za Baikalom [Tripods beyond Baikal]. In Sovetskaia arheologiia [Soviet Archeology], 3, 114-132.

Okladnikov, A.P., Larichev, V.E. (1969). Arheologicheskie issledovaniia v Mongolii v 1968 g. [Archaeological research in Mongolia in 1968]. In Izvestiia SO AN SSSR, Seriia obshchikh nauk [Proceedings of the Siberian Branch of the USSR Academy of Sciences, Series of General Science], 6, 2, 108-111.

Okladnikov, A.P., Zaporozhskaya, V.D. (1969). Petroglify Zabaikal'ia [Petroglyphs of Transbaikalia]. Leningrad, Nauka, $220 \mathrm{p}$.

Okladnikov, A.P., Zaporozhskaya V.D. (1970). Petroglify Zabaikal'ia [Petroglyphs of Transbaikalia]. Leningrad, Nauka, $264 \mathrm{p}$.

Okladnikov, A.P., Derevyanko, A.P. (1970). Tamcag-Bulak - neoliticheskaia kul'tura Vostochnoi Mongolii [Tamtsag-Bulak - Neolithic Culture of Eastern Mongolia]. In Materialy po istorii i filologii Tsentral'noi Azii [Materials on the history and philology of Central Asia], Ulan-Ude, Buriatskoe knizhnoe izdatel'stvo, 3-20.

Okladnikov, A.P, Kirillov, I.I. (1980). Iugo-Vostochnoe Zabaikal'e v epokhu kamnia i rannei bronzy [Southeastern Transbaikalia in the era of stone and early bronze]. Novosibirsk, Nauka, $176 \mathrm{p}$. 
Aleksandr D. Tsybiktarov. Genesis of Nomadic Cattle Breeding in Mongolia and Southern Trans-Baikal Territory...

Predbaikal'e i Zabaikal'e. Prirodnye usloviia i estestvennye resursy SSSR [Prebaikalia and Transbaikalia. Natural conditions and natural resources of the USSR] (1965). Moscow, Nauka, $492 \mathrm{p}$.

Preobrazhenskii, V.S., Fadeeva, N.V., Mukhina, L.I., Tomilov, G.M. (1959). Tipy mestnosti i prirodnoe raionirovanie Buriatskoi ASSR [Terrain types and natural zoning of the Buriat Autonomous Soviet Socialist Republic]. Moscow, Akademiia nauk SSSR, 218 p.

Sosnovskii, G.P. (1941). Plitochnye mogily Zabaikal'ia [Tiled graves of Transbaikalia]. In Trudy otdela istorii pervobytnoi kul'tury Gosudarstvennogo Ermitazha [Proceedings of the Department of the History of the Primitive Culture of the State Hermitage], Leningrad, Gosudarstvennyi Ermitazh, 1, 273-309.

Taishin, V.A., Lkhasaranov, B.B. (1997). Aborigennaia buriatskaia ovtsa [Aboriginal Buryat sheep]. Ulan-Ude, Buriatskii nauchnyi tsentr Sibirskogo otdeleniia RAN, 24 p.

Tipy mestnosti i prirodnoe raionirovanie Chitinskoi oblasti [Terrain types and natural zoning of the Chita region] (1961). Moscow, Akademiia nauk SSSR, 158 p.

Tsybiktarov, A.D. (1988). O konstruktsii pogrebal'nykh sooruzhenii kul'tury plitochnyh mogil [On the design of funerary structures of the culture of tiled graves]. In Pamiatniki epokhi paleometalla $v$ Zabaikal'e [Monuments of the Paleometal era in Transbaikalia], Ulan-Ude, Buriatskii filial Sibirskogo otdeleniia Akademii nauk SSSR, 40-60.

Tsybiktarov, A.D. (1989). Kul'tura plitochnykh mogil Zabaikal'ia i Mongolii. Avtoreferat dissertatsii na soiskanie uchenoi stepeni kandidata istoricheskikh nauk [The culture of tiled graves of Transbaikalia and Mongolia. Abstract of dissertation for the degree of candidate of historical sciences], Moscow, $24 \mathrm{p}$.

Tsybiktarov, A.D. (1998). Kul'tura plitochnykh mogil Mongolii i Zabaikal'ia [The culture of tiled graves of Mongolia and Transbaikalia]. Ulan-Ude, Buryatskii gosudarstvennyi universitet, $288 \mathrm{p}$.

Tsybiktarov, A.D. (2003). Sever Tsentral'noi Azii v epokhu bronzy i rannego zheleza. Avtoreferat disserttscii na soiskanie uchenoi stepeni doktora istoricheskikh nauk [North Central Asia in the Bronze and Early Iron Age. Abstract of dissertation for the degree of Doctor of Historical Sciences]. Novosibirsk, $49 \mathrm{p}$.

Tsybiktarov, A.D. (2006). Tsentral'naia Aziia na zare bronzovogo veka (konets III - pervaia polovina II tys. do n.e.) [Central Asia at the beginning of the Bronze Age (end of the 3rd - first half of the 2nd millennium $B C$ )]. Ulan-Ude, Buryatskii gosudarstvennyi universitet, $236 \mathrm{p}$.

Tsybiktarov, A.D. (2007). Formirovanie kochevogo skotovodstva v Tsentral'noi Azii v svete dannykh arkheologii i paleogeografii Mongolii i Yuzhnogo Zabaikal'ia i ego vliianie na kul'turno-istoricheskoe razvitie naseleniia bronzovogo veka [The Formation of Nomadic Cattle Breeding in Central Asia in the Light of Archeology and Paleogeography Data of Mongolia and Southern Transbaikalia and Its Influence on the Cultural and Historical Development of the Bronze Age Population]. In Etnoistoriia $i$ etnoarkheologiia Severnoi Azii: teoriia, metodologiia i praktika issledovaniia [Ethnic History and Ethnoarchaeology of North Asia: Theory, Methodology and Research Practice], Irkutsk, Edmonton, Irkutskii gosudarstvennyi tekhnicheskii universitet, 194-198.

Tsybiktarov, A.D. (2018). Skotovodcheskoe hoziaistvo nositelei kul'tury plitochnykh mogil Tsentral'noi Azii [Cattle-breeding economy of carriers of the culture of tiled graves of Central Asia]. In Mul'tidisciplinarnye aspekty izucheniia drevnei i srednevekovoi istorii [Multidisciplinary aspects of the study of ancient and medieval history]. Novosibirsk, Institut arkheologii i etnografii Sibirskogo otdeleniia RAN, 173-189.

Tseveendorzh, D., Bayar, D., Tseendagva, Ya., Ochirhuyag, C. (2008). Arkheologiia Mongolii [Archeology of Mongolia]. Ulaanbaatar, Akademiia nauk Mongolii, $239 \mathrm{p}$.

Vipper, P.B., Dorofeyuk, N.I., Metel'tseva, E.P., Sokolovskaya, V.T., Shuliya, K.S. (1976). Istoriia razvitiia rastitel'nosti Severnoi Mongolii v golotsene na osnove izucheniia donnykh otlozhenii presnykh ozer [The history of the development of vegetation in northern Mongolia in the Holocene based on the study of bottom sediments of fresh lakes]. In Biologicheskie resursy i prirodnye usloviia Mongol'skoi narodnoi respubliki, Struktura i dinamika osnovnykh ekosistem MNR [Biological resources and natural conditions of the Mongolian People's Republic, Structure and dynamics of the main ecosystems of the MPR], Leningrad, Nauka, (8), 35-59. 
Vipper, P.B., Dorofeyuk, N.I., Metel'tseva, E.P., Sokolovskaya, V.T. (1978). Opyt rekonstruktsii rastitel'nosti Zapadnoi i Tsentral'noi Mongolii v golotsene [Experience in the reconstruction of vegetation in Western and Central Mongolia in the Holocene]. In Geografiia i dinamika rastitel'nogo i zhivotnogo mira Mongol'skoi Narodnoi Respubliki [Geography and dynamics of the plant and animal world of the Mongolian People's Republic], Moscow, Nauka, 19-24.

Vipper, P.B., Dorofeyuk, N.I., Lijva, A., Metel'tseva, E.P., Sokolovskaya, V.T. (1981). Paleogeografiia golotsena i verkhnego pleistotsena Tsentral'noi Mongolii [Paleogeography of the Holocene and the Upper Pleistocene of Central Mongolia]. In Izvestiia Akademii nauk Estonskoi SSR, Biologiia [Bulletin of the Academy of Sciences of the Estonian SSR, Biology], 30, 1, 74-82.

Vipper, P.B., Dorofeyuk, N.I., Metel'tseva, E.P., Sokolovskaya, V.T. (1989). Landshaftno-klimaticheskie izmeneniia v Tsentral'noi Mongolii v golotsene [Landscape-climatic changes in Central Mongolia in the Holocene]. In Paleoklimaty pozdnelednikov'ia i golotsena [Paleoclimates of Late Glacial and Holocene], Moskva, Nauka, 160-167.

Volkov, V.V. (1967). Bronzovyi i rannii zheleznii veka Severnoi Mongolii [Bronze and Early Iron Ages of Northern Mongolia]. Ulan-Bator, Akademiia nauk Mongolii, 148 p.

\title{
Генезис кочевого скотоводства в Монголии и Южном Забайкалье: предпосылки и причины
}

\author{
А.Д. Цыбиктаров \\ Бурятский государственный университет \\ им. Доржи Банзарова \\ Российская Федерация, Улан-Удэ
}

\begin{abstract}
Аннотация. Раскрыты предпосылки и причины становления кочевого скотоводства в палеоэкономике степного населения Монголии и Южного Забайкалья. Проанализированы изменения, произошедшие в хозяйственных занятиях археологических культур региона на протяжении эпохи бронзы. Дана характеристика комплексного типа экономики населения селенгинско-даурской культуры времени энеолита - ранней бронзы, сочетавшей отрасли производящего и присваивающего хозяйства. Обосновано положение об оседлом образе жизни представителей селенгинско-даурской культуры. Показан номадный характер хозяйства и образа жизни населения культуры плиточных могил времени развитой - поздней бронзы. Смена скотоводства придомного типа кочевым скотоводством связана с аридизацией климата, начавшейся в конце III тыс. до н.э. и завершившейся в середине II тыс. до н.э. Выделены экономические, биологические и природно-климатические предпосылки перехода к номадизму, в том числе накопление опыта в сфере скотоводства в эпоху раннего металла, адаптационные способности разводимых домашних животных к содержанию под открытым небом, изменения в окружающей природной среде в направлении аридизации климата и ксерофитизации растительности степей. Причиной перехода к кочевому скотоводству было установление в регионе в середине II тыс. до н.э. резко континентального климата с жарким сухим летом и малоснежными зимами. Засушливый климат ухудшил условия для занятия земледелием, охотой, рыболовством и собирательством. Небольшая толщина снежного покрова в зимнее время позволила перейти к круглогодичному содержанию животных на подножном корму с периодической сменой пастбищ по мере их истощения.
\end{abstract}


В итоге произошла перестройка экономики степного населения на ведение кочевого скотоводства и сформировался подвижный номадный образ жизни населения.

Ключевые слова: бронзовый век, палеоэкономика, кочевое скотоводство, палеогеография, палеоэкология, междисциплинарные связи, аридизация, трансформация, селенгинско-даурская культура плиточных могил.

Научная специальность: 07.00.06 — археология. 